\title{
Normas para Publicação
}

Os textos submetidos ao periódico Atualidade Teológica, mesmo quando avaliados, revistos e publicados são de total responsabilidade dos seus autores.

Os autores devem ter título adquirido de pós-graduação (mestrado ou doutorado).

Os textos deverão ser inéditos. Podem ser pesquisas originais ou textos de revisão.

Todos os textos, seja de artigo, de comunicação ou de resenha, uma vez encaminhados para Atualidade Teológica, não devem ser propostos paralelamente a outro periódico. Isso só poderá ser feito se forem antes devolvidos pela revista Atualidade Teológica ou se houver uma desistência de publicação expressa da parte do autor.

As submissões e os demais contatos, incluindo-se para as correções solicitadas pela equipe editorial, devem ser feitos para o e-mail $<$ atualidadeteologica@puc-rio.br>.

Publicam-se textos científicos de teologia que atendam ao escopo e os objetivos de Atualidade Teológica e que tenham sido aprovados no processo seletivo, que passa pela pré-avaliação, a revisão por pares e os pareceres finais do editor ou de membros do conselho editorial.

As dimensões previstas para as contribuições são: de 10 a 12 páginas para artigos; de 6 a 8 páginas para comunicações; e de 2 a 5 páginas para resenhas. 
Incluem-se, na extensão prevista, o título, o resumo, as, palavras-chave, o corpo do texto, as referências bibliográficas, os dados do autor.

O formato da página é A4.

As margens do documento são; superior e inferior: $3 \mathrm{~cm}$; esquerda e direita: $2,5 \mathrm{~cm}$.

O espaçamento entre as linhas é simples, com 0cm para o "antes" e o "depois" de cada parágrafo, que terá $1 \mathrm{~cm}$ adentrado na primeira linha.

A letra deve ser na fonte Times New Roman: caractere 11 para o corpo do texto e caractere 9 para as notas de rodapé.

As citações com três linhas ou mais deve utilizar caractere 10, sem aspas, com recuo de $2 \mathrm{~cm}$ à esquerda e à direita.

Para fontes específicas de palavras ou citações em grego e em hebraico, deve-se entrar em comunicação com a secretaria da revista, e verificar envio das fontes correspondentes que são usadas pelo periódico.

O título e, se houver, o subtítulo do artigo ou comunicação, ficarão alinhados à direita, utilizando-se a fonte Times New Roman em negrito, caractere 18 para o título e 16 para o subtítulo. Título e subtítulo são separados por dois pontos (:). As resenhas têm como título a referência completa da obra analisada, o que também deve vir alinhado à direita.

Depois do título e do sub-título no idioma original do artigo ou comunicação (o idioma original pode ser em português, espanhol, inglês, francês ou italiano), devem vir o título e o subtítulo traduzidos para o inglês (se não for esse o idioma original).

O nome do autor do artigo, comunicação ou resenha, aparecerá duas vezes: no início do texto, abaixo do título-subtítulo, alinhado à direita, fonte Times New Roman itálico e caractere 12; e no final do texto, alinhado à direita, fonte Times New Roman itálico-negrito e caractere 12.

Apresentam-se o resumo (de 150 a 200 palavras) e as palavras-chave (5 no máximo). Em seguida sua tradução para o inglês - do "abstract" e "Keywords".

O corpo do artigo deve ter: a Introdução; as várias partes numeradas em algarismos arábicos com suas subdivisões, separando-se os algarismos por pontos: Por exemplo: 1. / 1.1. / 1.2. / 1.2.1. / 1.2.2 /... Ao final de cada seção salta-se uma linha. Ao final, Conclusão ou Considerações finais.

Segue a apresentação de Referências bibliográficas, nas quais devem constar todas as referências do artigo, em ordem alfabética, mas somente aquilo que foi citado (direta ou indiretamente). 
Após o nome do autor no final do texto, devem ser dadas as seguintes informações, cada uma em uma linha, todas alinhadas à direita: o nome do autor, em negrito e itálico; a maior titulação do autor e a instituição de ensino que lhe deu o título; sua filiação institucional e função na instituição; cidade, CEP e país da instituição à qual está filiado; e-mail para contato.

A indicação das referências bibliográficas ao longo do texto, para citações diretas ou indiretas, é feita em notas de rodapé.

Para as indicações bibliográficas nas notas de rodapé e nas referências ao final, faz-se uso das normas da ABNT (norma NBR 6023), mas com adaptações conforme mostrado nos exemplos que a seguir.

\section{Livro}

GOMES, C. F. Riquezas da Mensagem Cristã. Rio de Janeiro: Lumen Christi, 1983.

\section{Parte de livro}

FANULI, A. "As 'Tradições' nos Livros Históricos do AT. Novas Orientações". In: FABRIS, R. (org.). Problemas e Perspectivas das Ciências Bíblicas. São Paulo: Loyola, 1933, pp. 11-35.

\section{Artigo de periódico}

COSTA, P. C. "Diálogo entre Cristianismo e mundo cultural nos primeiros séculos". Atualidade Teológica 33 (2009), pp. 313-331.

\section{Verbete de dicionário}

COURT, J. M. "Millenarianism". In: COGGINS, R. J.; HOULDEN, J. L. (ed.). A Dictionary of Biblical Interpretation. London: SCM Press, 1990, pp. 459-461.

\section{Artigo de jornal}

BERTONE, T. "O Pai-Nosso deve ressoar na vida do cristão". L'Osservatore Romano, Roma, p. 1, 31 de julho de 2010.

\section{Citação eletrônica}

BERTONE, T. "O Pai-Nosso deve ressoar na vida do cristão". L'Osservatore Romano, Roma, 31 de julho de 2010. Disponível em: $<$ http://www. vatican.va/news_services/or/or_por/text.html\#1>. Acesso em 04 de agosto de 2010. 
Nas notas de rodapé, a primeira referência de cada obra citada deverá ser sempre completa. A partir da segunda vez em que a obra é citada, basta a indicação do autor, título (que, se for longo, pode vir abreviado) e página da citação.

Conteúdo, correção linguístico-ortográfica, forma e estilo dos textos submetidos são de inteira responsabilidade dos seus autores. A revista pode fazer sugestões ou exigências de revisão, mas fica isenta de responsabilidades, encargos ou ônus a esse respeito.

Os autores devem informar também, no e-mail do encaminhamento do texto o seu endereço postal e o seu telefone (com número de DDD/DDI). Essa informação ficará disponível para uso da revista e não será divulgada na publicação.

Os autores e as autoras serão notificados quanto à aprovação ou não do texto submetido.

Se a contribuição for aprovada, os direitos autorais são cedidos à Atualidade Teológica e fica autorizada a publicação do artigo, da comunicação ou da resenha nas duas formas de publicação da revista: impressa e eletrônica.

Pelos direitos autorais cedidos, os autores e autoras receberão três exemplares da revista impressa quando tiverem contribuído com um artigo e receberão um exemplar pela comunicação ou resenha. 